\title{
Maoist Combatants' Narratives: Partisan Attachment to Post-truce Politics
}

\author{
Khangendra Acharya \\ Assistant Professor of English, \\ Kathmandu University, Nepal
}

\section{Introduction}

Ten-year long war led by Communist Party of Nepal (Maoist) [hereafter CPN (M)] from February 1996 to November 2006 has been understood as one of the most violent times in Nepali history. The armed wing of CPN (M), People's Liberation Army (PLA) formed in 2001, was the armed group combating in the war front. Prior to the formation of PLA, CPN (M) had set up its armed groups differently: they had three-tier structure in 1994 that comprised combatant group, security group and volunteer group, which was transformed in 1997 into Guerrilla Squad, and in 1997 into Guerrilla Platoon. Subsequent transformations were Guerrilla Company in 1999 and Guerilla Battalion in 2000. All these groups were involved in armed actions of various magnitudes including selected annihilation, sabotage, ambush, raids and attacks. When the peace truce, the Comprehensive Peace Agreement (CPA), was agreed, CPN

(M) claimed that the party had 32,000 People's Liberation Army members, around 20,000 of whom were verified by the United Nations (UN).

Some of the combatants have rendered their experience in written accounts, which stand as testimony to these individuals' experience during the war. The writings, however, were not publicly available during the war time because the state had defined them as the instrument of terrorism. Only the secret presses published such writings in pro-Maoist magazines and newspapers; and these publications were disseminated to a very limited and intended populace. In 2006, that is after CPA, the prohibition over printing was lifted making it congenial for the armed forces engaged in insurgency to render their personal experiences.

Existing appraisals of these works is very scanty. Marie Lecomte-Tilouine has examined the concept of martyrdom presented in the textual testimonies; Khagendra Acharya has presented reading of three literary writings that present Maoist war; Michael Hutt has analyzed five memoirs written by the Maoist combatants; Khagendra Acharya and Orla Muldoon have studied four memoirs written by CPN (M) cadres engaged in war. In a sense, the available literature has not broached into substantial body of literature despite that fact that these writings contain a rich repertoire of personal experience while bearing witness to the happenings of the time.

The present article aims to examine substantial corpus of the combatants' narrative. Theanalysis presented here differ from the existing literature in that the present work provides summative and analytical reading of all the book length creative nonfictions written by the combatants. The texts included here merit further inquiries because they can be avenue to assess the combatants' understanding and experience of the war.

\section{The Texts}

In total 15 book length writings are analyzed in this article. These include Ajayshakti's memoir, Playing with Hurricane, Pasang'sRed Strides of the History: Significant Military Raids of the Peoples War, Devi Prasad Dhakal'sRadiance: Self- 
description till Gajuri Barrack Break, Lalit Shrestha's Initial Steps of the Revolution, Ganga Shrestha's From the Fort Palace to the Lion's Palace, Atom's Glorious History and Recollections of the War Fronts, Avinash'sIn the Battle Field, Laxmi Prasad Chalaune'sLife of the People's Army, Shyam Kumar Budha Magar's Those Stormy Days: Memories of a People's Liberation Fighter, IshworRijal'sThose Unforgettable Days, Dhaneshwor Pokharel's Memory of Beni Front: Word Picture, Uday Bahadur Chalaune'sIn the Red Army's Forts: Real Stories of Huge Combat in Sandhikharka, Lahan, Beni, Pili, Khara, Khairikhola, Sunawal, Palpa and Taulihawa, NabinJirel'sRemarkable Days, Sita B.K.'s Memories of War, Himmat Baral Magar's Journey of the War, and ShovaKattel'sMemories of People's War.

\section{Discussion}

The publication of book-length creative nonfictions written by the Maoist partisans is found to have begun from 2060 B.S. Prior to this year, only the memoirs of chapter length were published, mostly as a section of pro-Maoist magazines and newspapers. The year 2060 B.S. saw publication of six book length writings, among which five were anthologies of the partisans involved in the war and one was single authored book (Subedi). It needs to be emphasized that this was the time of ceasefire, and Maoist partisans were free to carry out their activities. But, as the ceasefire ended nearly after seven months, the publication of creative nonfictions came almost to an end: only one book came out in two years after the war broke out.The figure below provides information about the trend of creative nonfictions publication during and after the war.

\section{Figure 1: Maoist partisan written creative nonfictions}

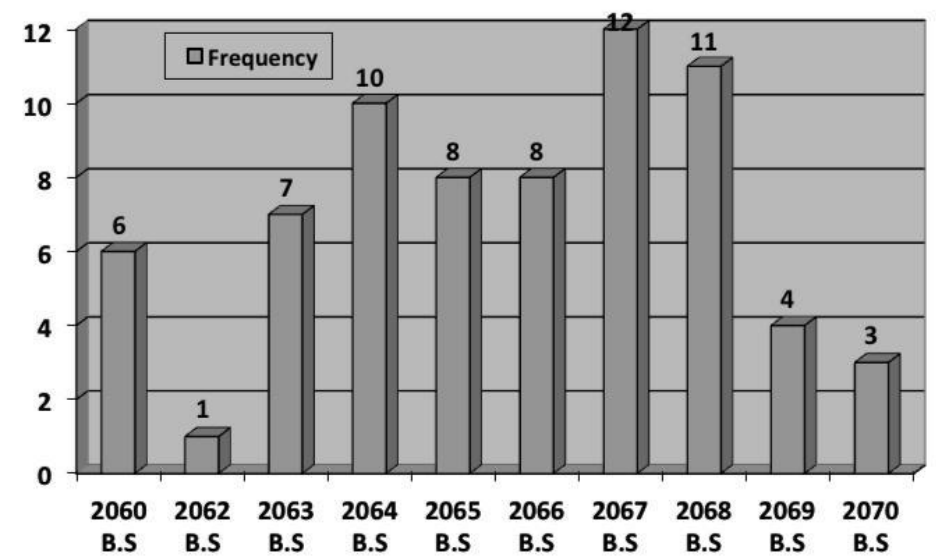

The trend of publication might be of an interest for scholars trying to understand facets of combatants' publication, especially political economy of printing books.

These writings render the combating partisans'experience in the war fronts, showing immunity of the Maoists. They reveal the preparations for military actions, stride of the combatants, attack in 'enemy or enemy's post' and retreat from the targeted site. Along with the narratives of armed actions, the books deal on partisan attachment, physical sufferings, life in incarceration and psychological distress. All the texts are read thoroughly, paying attention to partisan attachment, experience in the war front, tribute to the deceased, intraparty conflict and betrayal, experience of the distress, and perception of post-peace politics. 


\section{Partisan attachment: A range of causes}

Various factors ranging from exclusively individual to social are stipulated as the causes of partisan attachment. Shyam Kumar Budha Magar presents personal agony and loss, and social milieu and the role of some people in inciting him to politics. Devi Prasad Dhakal also acknowledges the role of multiple factors. Recalling his poverty-stricken family background and personal sufferings since his childhood, Dhakal confesses that these factors motivated him to partake in communist politics. He also highlights the influence of close relatives. The influence was so significant that even his father's objection and brother's counselling could not refrain him. Nabin Jirel, who was only 13 years old and unaware of party ideology, states at least three reasons: his meeting with a Maoist motivator, his willingness to transform society, and his willingness to take revenge against people who had been the cause of his suffering. Devi Prasad Dhakal considers unhappy life in the village, police personal's atrocious behavior, and other party cadres' abuse of authority as the causes of partisan attachment.

Ajayshakti points to single causation; he mentions that the social milieu was responsible for his politicization. He fleshes out numerous instances of social discrimination after the political upheaval of 1990 and the bureaucratic injustice that included the state security forces' atrocities and powerful individuals' suppression.

Early association with the Maoist partisans is presented as another major cause. Lalit Shrestha appears to have been motivated to politics from his school days due to an early association with his relatives and teachers. The fact that his uncle was killed in the initial days of the war instigated him to be a combatant; and later when he heard about his aunt's killing, he became more determined to take revenge. Atom's reason reiterates Lalit Shrestha's; Atom states that his early life experience contributed to party attachment. Two factors- his early exposure to communist ideology, and the state security force's torture to the whole family because of his father's partisanship with revolutionary communist party appear to shape pro-Maoist attachment. Similarly, Laxmi Prasad Chaulagain's initial interest in pro-communist politics was stimulated by a communist leader of his village and schoolteachers. From the leader, he understood that communists emphasize on equality, and from teachers he heard about the valiance of Maoist combatants. The fact that his society still sustained semi-feudal practices made him more proactive to join revolution against the feudal practices.

ShovaKattel's early interest in party politics was induced by family socialization, especially her relational proximity with a maternal uncle. The nearness inspired her to engage in student politics and finally in the party's underground activities. In Sita B.K.'s case, however, the family was non-supportive: she developed partisanship attachment with the Maoist despite the fact that her family was against communists.

\section{Experience of military action}

A number of books recall military action from the party's decision to the execution of armed attack. These narratives foreground the battlefront scenario, killing and being wounded, retreat from the front, and feeling at the death of co-cadres. 
Three authors - Pasang, Avinash and Uday Bahadur Chalaune - provide detail of major armed insurrections executed by the Maoist party. Pasang's narrative recalls descriptions of the targeted sites, military and logistic preparations for the war, tactical plans and implementations, achievement and loss, retreat from the site, and assessment of the entire mission. The description of the targets brings forth a sketch of physical location, architecture of the state security forces' camp, and their capacity in terms of security personals and artilleries. Another component, namely military preparations, presents the combatants' activities from reconnoiter to reaching the targeted site. The section describing execution of military action narrates how the combat commenced, what actions were taken, and how the opponents responded to the attack. This narrative presents pathetic predicament of the attacked, contrastingly different from that of the Maoists'. Yet, the other section - retreat presents numerous cases of trouble-free journey and a few instances of adversity-filled return due to the state security forces' aerial attack. Avinash's book presents actions and experiences related to military actions of various ranges. Starting forthright from the description of three consecutive guerilla attacks, the author renders experience related to military actions. The accounts related to the initial phase recall small scale attacks presenting reasons for selecting particular post, actions during the armed combat, and loss in the Maoists' and the opponent's side. In these sections, minute detail of the attacks can be read.Uday Bahadur Chalaune's memoir presents the Maoist cadres' engagement in various military executions. A number of armed actions are alluded and some are rendered in detail. In doing so, the author brings out various issues related to armed encounters, including difficult journeys while heading to the target, action packed armed encounter and retreat to the shelter. The narratives related to military executions render encounters in Sandhikharka, Lahan, and Beni, among others where they succeeded. In each story, the author shows preparation for the war, execution of the armed action, and retreat to the base area. There are also narratives that recall war fronts where they failed. Examples include description of attack in Khara, Ganeshpur and Rambhapur.

At least four combatants - Himmat Baral Magar, Ganga Shrestha, Devi Prasad Dhakal and Nabin Jirel - reveal their engagement in different types of military activities. Himmat Baral Magar was engaged in military activities of different nature including confiscation of contract papers from a money lender, manufacture of grenades and other weapons, participation in military training and execution of military actions. These narratives allude to dozens of military actions, brief about some of them, and present detail account of a very few. Narrative of military raid in Khara, for instance, tells story from planning phase till their retreat from the target. Brief stories of attack are in a larger number - narratives of PalpaHoleri raid, DumlaKhandaha encounter, Taulihawa attack, and Lunkhu raid, among others. These narratives present cases of armed combat like sabotages, selected annihilation, and major raids at the fort of state army.Ganga Shrestharecalls his involvement in various attacks. Initially, he was involved in small scale attacks; and later, he was involved in substantially large attacks. Some narratives tell about successful cases such as Lalbandi raid, and Bhiman attack; and others narrate Maoist combatants' mixed achievements - attack at Malanghawa instantiates a case of such type. Yet, other narratives instantiate cases of failed armed executions and the subsequent sufferings - their attack in Ghodetar of Bhojpur is a case in point. Like other narratives of armed action, this memoir presents the combatants' 
activities from the party's decision to attack, execution of attack, achievements as well as losses. In addition, it describes how the state force executed aerial attack, the loss caused by it in their part, and their narrow escape. Devi Prasad Dhakal's initial engagement included participation in protests against the local school authority. Later, he worked as a member of bomb manufacturer and participated in military raids in different capacities - as a volunteer, assault member, and commander. Other armed actions he took part included ambush, raid, sabotage and guerilla attacks. Then, he was assigned additional responsibility of supplying armed and ammunitions amidst tight security checking, and executing sabotages inside city area. Like Dhakal, Nabin Jirel's experience is also varied. Initially, Jirel was involved in military activities as a sentry, after which he took part in military training to get promoted to platoon runner then to militia commander and to member of a company.Then, he was involved in armed confrontations against the state security forces in nearly a dozen places. The narrative in this section presents preparations for the confrontation, description of the armed encounter, his contribution during the military actions, and the condition of combatants while retreating from the site of attack. Unfortunately, he had to discontinue engagement in war when was hit by bullet in one encounter. But when he got well, he returned to the war front again and took part in some retaliations. One narrative recalls Nepal army's unprecedented aerial attack when the Maoists were preparing for mass meeting: he was nearly killed this time; and the other time when they were coordinating retaliation against the army, he witnessed wounded and fallen cadres by the bomb dropped from the air.

Ajayshakti and Lalit Shrestha recall the stories of their involvement in combat before being wounded and after the recovery. Before injury narrative of Ajayshakti recalls confrontations of various magnitudes ranging from commando attacks to significant armed raids. Lalit Shrestha, on the other hand, tells that he got wounded severely in the maiden ambush that he laid. Following his wounding in an encounter with RNA and subsequent detention, Ajayshakti could not continue executing military actions. But, when he was released, he returned to his village, and convinced the party leaders that he would engage in the war again. He was then given vice-commandership of a company. What followed then was his involvement in military actions in Beni and Rukum attacks and Gandak Campaign. The narratives of attack not only demonstrate valiance of the Maoist cadres. Similarly, Lalit Shrestha got involved in numerous ambushes that killed many security forces. Further, he was involved in armed encounters including raids, sabotages and attacks to the stations of security forces. Threetypes of events are recounted prominently in the memoirs: defeat of the state force, the party cadres'retreat before their victory, and the cadres'heavy-hearted return after their defeat.

Shyam Kumar Budha Magar's memoir recalls combat experience extensively. The stories of military actions present instances of sabotage, selected annihilation, guerilla actions, police post raid, and retaliation against aerial attack. In addition, it recalls an incident of narrow escape from state security force, and compares his state of mind and that of some friends before going for armed actions. Atom (nom de guerre for Nirmal Mahara) renders instances of around a dozen raids and attacks by the PLA combatants and a few counter attacks by the state security force. Most of these accounts narrate preparation for attacks, casualties in the opponent's side, martyrdom of co-combatants, achievements from the war, and the Maoist combatants' retreat. Ishwor Rijal provides glimpses of military actions carried out in the eastern and central part of the country.His narrative presents instances of raids and 
sabotages. And, like many other accounts, he narrates not only the stories of success but also of the incidents of Maoist cadres' sufferings. Laxmi Prasad Chalaune'srendition of episodes related to military front reports about military actions in seven major executions.

Dhaneshwor Pokharel recounts 12 hours fiercest offensive in police posts, army barracks and a district office in Beni. Unlike many other narratives of military actions which render experience in multiple fronts, this memoir differs in two respects: first, it focuses on a single front; and second, it describes facets of medical management during the war. The content is presented in eight sub-headings. These eight subheadings can be regrouped in four themes: preparation for the war, execution of military action, management of the wounded combatants, and retreat to the base area. The content related to the first theme explicates the party's central committee decision in the context of political happenings during the time, and their journey towards the targeted place. The second theme relates to armed combat; it presents the combatants' journey, coming together of different brigades, and the execution of attack. The third section spotlights the role of health professionals during and after the war it reveals how the medical professions provided health service to the wounded combatants despite their limitations. The fourth theme narrates the combatants' retreat to their base area; the narratives in this section recall how the Maoist combatants communicated with the capsized people, and maintained Geneva Convention in their treatment to them.

\section{Tribute to the deceased}

The narratives of tribute abound in the corpus. Ganga Shrestha has extended tribute to party cadres who sacrificed their life for Maoist cause. One narrative, for instance, describes inspiring personality of Ichhuk, acknowledges his contribution and expresses distress at the news of his death. Another narrative pays homage to two party cadres with the focus on their contribution to the party.

Other combatants who have extended tribute include Laxmi Prasad Chalaune, IshworRijal, Lalit Shrestha, Avinash, and Atom, among others. Laxmi Prasad Chalauneextends tribute to co-combatants regretting for the fact that he could not sacrifice his life. IshworRijalextends tribute to the comrades focusing on the deceased comrade's family background, their contribution to the party, and how they were murdered by the state security force. Lalit Shrestha also extends commiseration to the martyrs' spouse who lost their partner in the war.Atom extends passionate tribute, expounding on the contribution of the comrades.

\section{Intra-party conflict and betrayal}

Critical reflections also find space in the narratives. These reflections show conflict within the party and instances of betrayal. ShovaKattel recalls a few instances of conflict among the cadres and their betrayals. For instance, in RNA detention some party cadres betrayed the party by informing whereabouts of their leaders.

Himmat Baral Magar also indicates an instance of betrayal. He believes that their troop's failure to execute military action was due to the exposure of their plan to the state force. Similarly, he expresses dissatisfaction upon knowing intra-party conflicts. Avinashhas also narrated his feeling at the party's decision to assign him to the political wing of the party, his dissatisfaction at the party cadre's deceiving activities when he had gone to meet his wife. 


\section{Experience of distress and the causes}

Many of the partisan's narrative present instances of distressful experience. Major causes of distress appear to be the death of close relatives or the party cadres. ShovaKattelpresents a number of distressing factors: she experienced torment upon hearing the martyrdom of her husband, suffered torture at the in-law's inhospitable behavior when she went to meet her two-year-old son, and felt torment at discriminatory treatment of the party cadres.Even some party cadres caused distress. For instance, when she decided to partake in the military activities following five month's detainments in civil security force's custody, some party leaders behaved in non-responsible ways. Like Kattel, Sita B.K. narrates in detail the causes of distress: once, she was wounded in the battle field; and the other time, she heard the news of her husband's death.

Himmat Baral Magar experienced distress at the loss of senior party leaders. Avinash's distress was caused by the death of close cadres. Ajayshakti'snarrative also render the experience of personal distress at the co-combatant's martyrdom. The most distressing moment was the time when he knew that his friend's left him alone in severely wounded condition. In this sense, the cause of distress is the failure of his comrades to maintain comradery.

Atom also gives expression to personal emotion/opinions: he recalls the distress caused by their troop's defeat and at the death of senior party leaders/combatants.Ganga Shrestha's narrative also does not refrain from expressing personal distress. He experienced distress when he was tortured excruciatinglyand incarcerated inhumanly. NabinJirel'smemoir is filled with the narrative of distress, the cause of which are idiosyncratic behavior and activities of the party members: infidelity of the party cadres and brutality of the senior leaders. Uday Bahadur Chalauneexpresses distress at their forces' inability to get hold of entire camp of enemy. Interestingly, though he was wounded in the battle field, this issue does not come out well. So is the case while expressing personal distress at the co-cadre's death.

\section{Perception of post-peace politics}

Most of the combatants' narrative express skepticism if not dissatisfaction at the postpeace politics. Sita B.K., who represented the Maoist as one of the members of parliament, expresses anxiety and concern at the future of the party. Another member of interim constituency, ShovaKattel, touches upon the issue of sectarianism in the party and reveals dissatisfaction at the party leaders' fascination towards parliamentary politics, sidelining the martyrs' dream to fight till their goal is not met.

Like these two members, those outside the constituency have also shown dissatisfaction at post-peace politics. Laxmi Prasad Chalauneexpresses doubts and dissatisfactions at the party's decision to confine their army to UN cantonment: he sees the martyrs' dream not given due respect. Along the same line, Lalit Shrestha states his dissatisfaction.For him, handing down the responsibility of their supreme leader's security to state security force was disheartening.NabinJirel considers his decision to opt for voluntary retirement scheme and leave the cantonment painful; he felt that the money was given in return of his dream while joining the combat. IshworRijal, on the other hand, presents serious concern at the marked differences in the post-peace activities of the party and her cadres. He 
shows concern about intra-party conflict and feels afraid at the danger of party going off the track.

Ganga Shrestha's post-CPA ruminations unlike that of Sita B.K. and ShovaKattel, do not read negatively laced; rather, he presents point wise assessment of the government's activities and the role of Maoist parliamentary members.A few other combatants are skeptical; yet, they maintain hope for the accomplishment of the party's mission.Ajayshakti, for instance, questions the Maoists army's verification by the UN and expresses feeling of loss at depositing their weapons in UN's custody. However, he states that the combatants' confinement in the barracks, was an obligation. Similarly, he feels that the combatants in cantonment are living better life compared to the hardship of their comrades' life, and yet, consoles with the understanding that this as a part of obligation.

\section{Conclusion}

The summative and analytical account of 15 creative nonfictions written by the Maoist combatants' gives rise to a number of conclusions. Firstly, the combatants' reasons for partisan attachment are not homogenously uniform: not only personal but also social and ideological causes are forwarded. Secondly, the narrative of military front foreground instances of Maoist combatant won cases; this, however, does not mean that there is absence of failed attempts. Thirdly, the combatants had passionate attachment with the comrades; and thus, when anyone died, the combatants paid tribute to the deceased. Fourthly, intra-party conflict was very common phenomena; and, very often the conflicts begot betrayals. Fifthly, the combatants experienced distress in a number of occasions. Major causes of distress were witnessing/hearing the news of family/cadres' killing, infidelity of the party cadres and failure to defeat the opponent in armed encounter. Some writings such as Pasang'sRed Strides of the History, however, have refrained from embodying distress experienced at the death of co-combatants. Lastly, post-peace politics, for many combatants, was not promising: they saw decadence of the war that the party had waged.

From the abovementioned conclusions, at least four research questions appear to be meaningful: a) Do the reasons of partisan attachment impact the nature of partisan attachment, particularly in terms of their commitment?b) How do the narratives of failed encounter resemble/differ from the narratives of successful cases? c) How was betrayal understood by the combatants and how did they address such phenomena? d) Why are some narratives entirely silent about distress? and e) What course of action have the dissents to post-peace politics taken?

\section{Works Cited}

Acharya, Khagendra, and Orla T. Muldoon. "Why "I" became a combatant: A study of memoirs written by Nepali Maoist combatants."Terrorism and Political Violence 29.6 (2017): 1006-1025.

Acharya, Khagendra. "Trauma of Maoist Insurgency in Literature: Reading Palpasa Café, Forget Kathmandu and Chhapamar ko Chhoro." Bodhi: An Interdisciplinary Journal (2011): 90-120. 
Ajayshakti, (nom de guerre for Surul Pun Magar). AandhisangaKhelda [Playing with Hurricane]. Ed. NabinBibhas. Na: People's Liberation Army (5th Division) and Brothers News Agency, 2066 B.S. [2010].

Atom (Nirmal Mahara). GaurabshaliItihaas ra YuddhamorchakaaAnubhutiharu (Glorious History and Recollections of the War Fronts). Kathmandu: RaktimPrakashan, 2063 B.S.

Avinash. JangakoMaidanmaa (In the Battle Field). Ed. Hira Mani Dukhi. na: People's Liberation Army, 5th Division, 2067 B.S.

Baral Magar, Himmat. Summer Yatra (Journey of the War). na: Kalpana Kauchha 'Ritu', 2067 B.S.

Budha Magar, Shyam Kumar. TiAandhimayaDinharu: EakJanamuktiYoddhakaa Sansmaranharu (Those Stormy Days: Memories of a People's Liberation Fighter). Ed.

NabinBibhash. na: Bhim Kumari Batha Magar, Mangsir, 2064 B.S.

B.K., Sita (Samjhana). YuddhavitrakaaSansmaran (Memories of the War). Kathmandu: B.N. PustakSansar, Magh, 2068 B.S.

Chaulagain, Laxmiprasad. JanasenakoJivan (Life of the People's Army). Butwal: JanaaawhanSaptahik and the Publication Unit of 4th Division, 2064 B.S.

Chalaune, Uday Bahadur 'Dipak'. Janayuddha ra JanamuktiSena: Saidantik Aadhar ra Karyaniti (The People's War and People's Liberation Army: Ideological Foundation and Strategy). na: People's Liberation Army, 6th Division, Baishak, 2066 B.S.

---. LaalmorchakaaKillaharumaa: Sandhikharka, Lahan, Beni, Pilli, Khara, Khairikhola, Sunawal, Palpa ra TaulihawakaBhisanLadaikaBastabikKathaharu (In the Red Army's Forts: Real Stories of Huge Combat in Sandhikharka, Lahan, Beni, Pili, Khara, Khairikhola, Sunawal, Palpa and Taulihawa). Kathmandu: Bibek SrijanshilPrakashan Pvt. Ltd., Mangsir, 2064 B.S.

Dhakal, Devi Prasad. Ujjyalo: GajuriByarekBreaksammakoAaatmabritanta (Radiance: Selfdescription till Gajuri Barrack Break). Kathmandu: JhilkoPrakashan, Jestha, 2068 B.S.

Hutt, Michael. "Reading Nepali Maoist Memoirs." Studies in Nepali History and Society 17.1 (2012): 107-142.

Jirel, Nabin.BhisanDinharu (Remarkable Days).Kathmandu: Nepalaya, 2013 [2070 B.S.].

Kattel, Shobha. SamarkaSmritiharu (Memories of People's War).Chitwan: Samar-Prateek Mashik, 2068 B.S.

Lecomte-Tilouine, Marie. "Kill One, He Becomes One Hundred: Martyrdaom as Generative Sacrifice in the Nepal People's War.” Social Analysis 50.1 (2006): 51-72.

Pasang. ItihaaskaRaktimPayilaa: JanayuddhakaaMahatwapurnaFoujiKarbahiharu (Red Strides of the History: Significant Military Raids of the People's War). Trans. Sushil Bhattarai. Kathmandu: AgniparikshaJanaprakashanGriha, 2064 B.S.

Pokharel, Dhaneshwor. Beni Morchako Smriti: Sabdachitra (Memory of Beni Front: Word Picture). Kathmandu: Akhil Nepal Lekhak Sangh, Bhadra, 2067 B.S. 
Rijal, Ishwor. BirsanaNasakineTiDinharu (Those Unforgettable Days). na: IshworRijal, Bhadra, 2067 B.S.

Shrestha, Ganga. GadhiDarbardekhi Singh Darbarsamma (From the Fort Palace to the Lion's Palace). na: PN (M) Kochila Rajya Samiti PrakashanBibhag, Ashad, 2067 B.S.

Shrestha, Lalit. KrantikoKakhara (Initial Steps of the Revolution). np: Sarada Printing Press, 2068 B.S.

Subedi, Ashok. "Preface to Edges of Memory: Word Witness to Class Struggle." Edges of Memory. Kathmandu: Shami Sama PrakashanGriha, 2070 B.S. 